\title{
Digital Dose of Didactics: Reinforcing Patriarchy through Moral Stories on YouTube
}

\author{
Gopika Sankar U. \\ Assistant Professor, Dept. of English, University of Hyderabad. Email: ullatgopika@gmail.com
}

\begin{abstract}
Should girls get a formal education? Should women earn? And who should handle the money they earn, if at all? Can a woman's personality be tied to learning and earning? These questions may be easily overlooked in the $21^{\text {st }}$ century, when women have forayed into almost all possible careers. However, these and more questions related to women's education, employment and empowerment find clear answers in the so-called moral stories in Hindi and other Indian languages, one finds on YouTube these days. The paper analyzes a selection of such stories centered on women and argues how these 'moral stories' ultimately emerge as schemes to keep the patriarchal structure alive by creating an easily accessible digital repository, and end up patronizing women in the pretext of empowering them. The paper focuses particularly on the idea of 'moral' these stories contain and argues that the moral messages they convey are actually detrimental to the empowerment of women as their deep structures work to cement the foundations of patriarchy.
\end{abstract}

Keywords: Moral, Digital, YouTube, Stories, Patriarchy.

\section{Introduction}

These days, YouTube sees a constant upload of animated stories in Hindi and other Indian languages in the genre of Moral Stories, many of which have millions of views. These stories tagged 'Safalta' or Success stories, moral stories, comedy videos, etc. portray issues related to family, society, employment, and so on. The paper looks at a selection of such stories in Hindi, which discuss women's education and employment, but ultimately underscore the glory of sacrifice: the good wife and the good daughter-in-law who is docile, who dedicates herself to her husband's family as opposed to the bad one who does not want to be enslaved to her husband and in-laws. The paper probes into their denotation and connotation to uncover the subtle yet deeper messages they convey, and argues as to how they serve to reinforce patriarchal values in $21^{\text {st }}$ century digital India. The paper contests the notions of women's empowerment and the image of a successful woman these stories try hard to represent but ultimately emerge as superficial caricatures of empowerment in the deeper structures of domestic morality and the didactic element of the good versus evil woman they contain, an antithesis to the messages they supposedly portray.

\section{An Analytical Overview of Select Stories}

This section analyses a selection of stories in Hindi with millions of views. It will translate the ideas into English, without, however, quoting extensively from the videos. While there are hundreds of

This Open Access article is published under a Creative Commons Attribution Non-Commercial 4.0 International License (http://creativecommons.org/licenses/by-nc/4.0/), which permits non-commercial re-use, distribution, and reproduction in any medium, provided the original work is properly cited. For citation use the DOI. For commercial re-use, please contact editor@rupkatha.com. 
stories on YouTube these days as moral stories, some of them are mere animated versions of the saas-bahuii soaps one finds on television channels, but the ones discussed here are those which strive to create images of a successful woman or those supposedly meant to empower women in some way or the other. The following sub sections analyse 2-3 stories grouped in a thematic classification.

\subsection{Caricatures of Empowerment: The "Safalta"iii Stories}

"Samosawali ki Safalta" ("The Samosa Seller's Success") by MaJa Tv Hindi Stories presents the story of Suguna who saves her family by selling samosas. When her father-in-law, a jeweler, has to incur a heavy loss in his business, the elder daughter-in-law, Suguna, saves the family by selling samosas, following her brother's suggestion. While the story apparently highlights Suguna's success, it clarifies that she is illiterate and from an economically backward family and clarifies that the younger daughter-in-law who is educated, and who is generally "lost in her books" (0:50-58) does nothing during the crisis. The story seems to suggest that an educated girl/woman who has had a comfortable life is basically "useless", while the illiterate one is "of use." The younger daughter-in-law's exclamation that one cannot earn respect living in one's mother's home reveals the underlying patrilocal structure which holds that a married woman's place is in her husband's home and moreover, a man who lives with his in-laws will earn no respect (5:51-56). Thirdly, we see how neither of the sons is blamed when they can't work and earn during hard times. The elder son's inability to hold on to a job is excused as he is not wont to hard work having grown amidst luxury (2:05-10), while the same logic is not applied in the younger daughter-in-law's case. The story also shows that Suguna stops selling samosas and gives her samosa cart away to her assistant, once her father-in-law resumes his trade, thus suggesting that a woman needs to take up a financially rewarding job only for her husband's family's sake and not for herself or that there is no need for her to be financially independent. The story thus clearly instills distinct gender roles and norms and a different kind of logic for women and men. More than playing on the idea of masculinity, the story works by manipulating the 'feminine' ideals of patience, hard work, sacrifice, humility, docility, etc., for there is no demand on the men of the family to think of an alternative when the ship sinks but rather the test is on the virtues of the daughters-in law in building back the abode. The video has mostly positive comments appreciating the story, with even comments that the younger daughter in law should not have been excused but taught a lesson.

In "Machiwali ki Safalta" or "The Fisherwoman's Success" by Koo Koo TV-Hindi, we see a nuclear family sort of setting, where an educated employed man, Yogesh marries an illiterate woman, Shewantha, who is from a fishing community. When Yogesh loses his job, Shewantha saves the family by selling fish. Shewanta definitely has long days where she has to do the household chores, buy and sell fish by walking on foot all day long, while her husband goes jobhunting every day and returns home disheartened. However, this man is given a soothing head and foot massage by his dear wife, who is always fresh and strong even after a long day (3:34-37). Shewanta too gives away her savings to her husband for starting a business. The message is loud and clear here too: that a woman should earn only for her husband and his family, and even while working full time on a job, she should fulfill her homemaker's role and serve her husband and family without brooding. 
At the surface level, "Choti Bahu Bani Collector" ("The Younger Daughter-in-Law Became a Collector") by MaJa TV Hindi Stories shows the importance of women's education. The younger daughter-in-law, Suguna continues her studies post marriage and becomes an IASiv officer, a District Collector to be precise, despite her difficult marital life and limiting circumstances. Her father arranges her marriage after her Grade X, but she acquires a B.A. degree through distance education programme, following which she works as sales assistant in a small textile shop. Suguna gives away her salary to the family, besides doing household chores and silently bearing the verbal abuse of her sister-in-law, Vimala, during this period. Strangely enough, nobody in the village even gets to know of Suguna cracking the IAS examination, although the result of this examination generally gets a lot of media attention. Even shocking is Suguna's response to Vimala when the latter attempts an apology for her rude behaviour. Suguna, without mincing her words, simply says had she been in Vimala's place, she too may have behaved like Vimala (14:16-25), thus justifying ill-treatment and abuse. This attitude is not ethically or politically correct coming from anyone, especially so, from a top cadre bureaucrat, someone who is often looked up to as a role model in the Indian society. The story ends with the message that teaching a girl helps to build not only a family, but a village or even a nation, which clearly points to the need to provide a justification for creating a story about a woman who continues her studies after her marriage.

"Naukriwali Bahu" or "Working Daughter-in-law" by Bedtime Stories of KidLogics Hindi Stories "educates" the viewers on the need to let women take up a financially rewarding job as opposed to tying them down as homemakers. The mother-in-law, who forces her daughter-inlaw to give up her job, comes into terms with the "need" to let her work to cope with the mounting expenses of our times. The husband simply nods to whatever his mother says and is not supportive of his wife's ambitions, but puts pressure on her to take up a job when he cannot manage things on his own. And the moral of the story is that one should move with the current (6:02-06), reinforcing the idea that women should be "allowed" to take up a financially rewarding job to run the household and not because she is an individual with her own likes, wants and ambitions.

"Road Roller Wali Bahu" ("The Daughter-in-law on a Road Roller") by Koo Koo TV-Hindi is sort of a fantasy tale of a young woman stuck on a road roller during daytime, by default. After her marriage, as she cannot get down from the road roller during the day and help with the chores, and also as expenses mount on account of maintaining the vehicle, the father-in-law gets irritated and asks the couple to move out. They, however, eke out a living, making use of the road roller for its designated purpose, and in no time make a lot of money. The old man then welcomes them back, ultimately suggesting that a daughter-in-law is worth only the money or material things she brings in. Before the marriage, the son too is worried whether the girl will be a "burden" but considers her beauty as a saving grace. Thus, had she not been "beautiful," she would have been rejected. And had she been challenged in some other way, say, physical disability, would she hahave been forced to convert that into a means of living too?

Many of these animated stories seem to be inspired by the life stories covered by mass media and shared on social media. Success stories of start-ups, small businesses, YouTube channels, etc. flood the social media these days. Lilly Irani's book Chasing Innovation which examines the fast-expanding start-up and small business environment of India sees this spurt as part of the state's "entrepreneurial citizenship" making project and hence with ruling class ideologies imbued in them (Irani, 2019, p. 44, 202-203), while also recognizing that the "call to 
entrepreneurial citizenship is global" (p. 205). The animated success stories found on YouTube may be promoting this motive or simply reflecting this trend. They may also be reflecting the life stories of the channel creators to some extent, at least in select cases. For instance, Durgaram Chaudhary who owns Koo-Koo TV, along with his wife, is someone who did odd jobs and small businesses from a very young age before he established himself in the media business, as per some reports (Kapoor, 2020).

\subsection{Fallback in Times of Crisis or a Digital Backing of Dowry?}

In "Sheher ki Saas" or "The City-Bred Mother-in-law" by Bedtime Stories, we see an ill-tempered mother-in-law who finds fault with her daughter-in-law, Sita, whatever she does, as the latter is a simple woman raised in a village. She is treated like a work horse and not allowed to attend social events. However, things get better for Sita when her husband faces a terrible loss in business, and Sita's father saves the family by paying their debts off. This softens mother-in-law who confesses that a daughter-in-law is equal to a daughter and that Sita has fulfilled her role as a daughter. Here too, the emphasis is on the role of a woman as a homemaker and how she needs to be not only resourceful but also 'useful' during hard times. A deeper analysis of the story also unravels the deep structure behind the idea of the father-in-law paying off his son-in-law's debts: the dowry system: justifying it as a fallback in times of financial distress, whether given to the groom's family before or after marriage. One cannot but wonder what would have happened to Sita had her father not settled the debts.

KirraK TVs "Bulldozer Marriage Kahani Comedy" implicitly encourages dowry system in the garb of a comic video. A guy decides to marry his girlfriend as soon as he gets job as a probationary officer with a bank. He wants a big fat wedding and expects his prospective millionaire father-in-law to sponsor the entire event; a major demand of his being a mammoth vehicle for the couple. When the father-in-law plays a practical joke by gifting the son-in-law a bulldozer, the latter turns irate and sends off all the maintenance bills of the vehicle to the fatherin-law who finally replaces the bulldozer with a sports car. The daughter does not question her husband's demands, but just hopes her father would keep him happy. This can be seen as an instance for demanding, giving and accepting dowry. Not only is the young man not ready to share the expenses of his own wedding, but he also expects the father-in-law to pay for his expenses even after the wedding. The practice of bearing of wedding expenses exclusively or majorly by the bride's family is often a cause for concern, and even a cause for breaking off of engagements, as seen in Ishita Das's case: "Recently, my highly educated partner of four years broke off our free-choice relationship, incapable of coping with societal pressure from his family. Their reasoning was ... My 'unconventional' independence, with a subtext of denied dowry (in their words - 'wedding expenses of their high expectations')" (in Dholakia, 2015, emphasis original). ${ }^{v}$ One can still come across media reports on domestic abuse and harassment faced by women on account of dowry related issues from time to time. Thus the "Bulldozer" story can be anything but comical.

In the fourth story in "Magical Bakery Wali" of Hindi Stories for Kids, a chef Premji is depicted to be worried about his sister's marriage and brother's education: "behen ki shaadi and bhai ki padhai" (24:07-25:04), and later conducts his sister's wedding by borrowing money from 
5 | Digital Dose of Didactics: Reinforcing Patriarchy through Moral Stories on YouTube

his village feudal lord. Thus, we see how such notions - as a girl connoting to a mere marriage material and a boy as meant for studies and employment - which should be long redundant being directly or indirectly instilled in young minds. That the bride's side has to bear the wedding expenses is underscored here too.

\subsection{Of Body Politics}

"Gol Matol Bahu" ("The Fat Round Daughter-in-Law") by Koo Koo TV portrays a young woman Maithili as dull, sluggish and unable to perform her chores well (1:30-40, 1:56-59), and attributes it to her body weight. Her in-laws are unhappy about Maithili's body and her sedentary lifestyle, and come up with a plan through which she is shown to evolve into a smart "beautiful" (5:13), active and healthy woman. The story depicts that a woman who is not slim is not beautiful or active. Moreover, it shows that Maithili grows fat as her father used to love and pamper her so much (1:11-18) and hence it becomes the duty of the in-laws to provide corrective measures for her shortcoming. This can be problematic too as it suggests that daughters should be made to do housework or else, they will grow fat, round, slow and not "good-looking" and thus a burden for the family. The story also gives this strong message as to how a daughter can be a cause of concern for a parent and how arranging her marriage is the only remedy to this (0:13-36).

"Mooch Wali Ladki" ("Moustache Girl") by Red Tomato identifies hormonal imbalance as the reason for excess facial hair in women. But instead of creating a positive body image or encouraging women to seek medical treatment for correcting hormonal balances, it portrays such a woman as unhappy and 'unmarriageable.' She goes to work, covering her face to save the embarrassment of being seen with a moustache. Further, it depicts the issue to be resolved with a simple upper lip wax, reducing the condition to be a mere cosmetic issue. The procedure improves her marriage prospects suddenly. What Neel Burton observes is righty applicable here: "Beyond a certain age, a man who remains unmarried is thought of as independent or intelligent, whereas a woman who remains unmarried is assumed to be desperate, at once a figure of pity and scorn" (2017). The story delineates a significant sensitive issue carelessly and ends with a disempowering message. Another such story "Moochowali Ladki" ("Girl with a moustache" again) by KOO KOO TV is even weirder in that a girl is shown to grow arrogant as her father pampers her, and is finally cured of her arrogance by a mango tree which curses her to grow a moustache as a lesson for hurting the tree. The intended message of discouraging environmental degradation thus gets drowned in the didactic tone of suggesting a bodily condition as the result of one's bad karma and ultimately justifying body shaming, as people are seen laughing at the girl because of her condition. And what's worse, this story is shown as one for minors with the commenting option and the mini-player disabled. As Purnima Ojha rightly observes, "There are many instances of mistreatment of women by Indian media and not much has changed regarding portrayal of woman" $(2011,99)$. The digital media is no exception to this and instances of body shaming, slutshaming, bullying, etc. can be found aplenty here. Thus, in a society haunted by rampant abuse in real and virtual spaces, conveying messages which apparently justify abuse as "Moochowali Ladki" by Koo Koo TV does, may serve to their normalizing in the viewer's minds.

From another perspective, this is in line with many of the didactic tales found in ancient Indian fables, which highlight the intervention of Nature in molding fallen individuals. As Leela 
Arjunwadkar notes, "Incidentally, in all (Sanskrit) didactic fables, where human beings tread a slippery path, it is the birds or beasts that show the right moral track ..." (1984, emphasis added). However, in the "Moochwali" story, as a bodily issue is attributed to a curse by a tree, it leads to questionable ways of addressing both bodily issues and environmental issues.

\section{Inference}

One of the animated stories itself shows the psychological makeover media can induce on its viewers. For, in the story, "TV Serial" by Jadu TV (in the video "Dosawali ki Safalta"), we see a woman who is addicted to television soaps, who becomes oblivious of everything around her. While the story insists on not following TV soaps to heart, the so-called moral stories are created to act as didactic, and in that sense, are meant to reform the viewers, whether children or adults. According to Richard Probst, literature imparts five kinds of knowledge: "knowledge of the self, knowledge of others, knowledge of texts, knowledge of contexts, and knowledge of processes (of making meaning)" [In Nelms (ed), 1988, p. 27]. vi The moral stories on YouTube too as animated literary compositions can provide these kinds of knowledge. If we look at the knowledge of self, the stories do not inspire a self-realization from within but from without. That is to say, a woman viewer, while looking into herself in an attempt to identify her strengths or goals, is encouraged to see herself as the world wants her to. Can she focus on her career without attending to the domestic duties imposed on her by the society? When a woman looks at her own image, what does she see? Her own self or what others see in her? Should she assess her self-worth based on her appearance or her worth in the marriage market? The knowledge of self as something arising from deeper within one's being is little emphasized by these moral stories. The rest of the knowledge creation emerge as outputs of an inherent patriarchal structure and the need to keep it intact, whatever a woman's station in life. Meaning making by viewers would of course depend on whether they critique the text or simply internalize the stories and the morals without questioning them. But since these stories are in the form of animated videos, they can easily attract children and hence become a cause for concern. Even channel names like Bedtime Stories (Kidlogics) and titles like fairy tales are also misleading, despite the age defined disclaimers with many of the videos. Old or young, formally literate or not, the viewers are given subtle doses on the need to control women, keep them docile, exploit their skills for their husband's family and curb any trace of assertive behavior or independent thinking in the women. In my opinion, if such stories are repeatedly watched by children at an impressionable age, it can ensure the continuity of these values in the long run.

Peter Smagorinsky and Joel Taxel point out how the "power of adults and cultural icons is central to a character education approach in which adults have unassailable authority in providing direction to young people's moral development" (2010, p. 43). vii Here, in many of these videos, interestingly, the morals are prescribed not just to children or younger people but to older adults as well. The intention of moral stories for children is self-explanatory in that they are meant to influence the young minds and their development. But what is intended by moral stories for adults? To bring about a change in their attitude and behaviour? To suggest corrective measures for their flaws and follies? And when these flaws and follies are clearly defined by gender variables, 
are these didactic messages meant for women to conduct themselves in certain ways as wives, daughters-in-law, and so on?

Does the "moral" in these stories connote to reinforcing of patriarchal ideals? Why does a story like "Samosawali ki Safalta" portray an educated woman as arrogant and unresourceful? Is it to suggest that education is wasted on a woman and does not serve her own or others' good? Education is not seen as one's right here but as a choice which may be adopted or abandoned according to one's circumstances. There are plenty of stories too where men are portrayed as vain, greedy, etc. like "Lalchi Ghee wala", Lalchi Mithaiwala (Greedy Ghee Seller, Greedy Sweet Seller respectively, both by Hindi Kahaniya), etc. but they concern humanity as such, while those centered on women are patronizing in how the meaning of gender is constructed. The stories concerning women espouse a clear ideological agenda by proclaiming to contain a moral which is patriarchy driven.

Existing societal ideologies are converted to digital "semiotic ideologies" (Keane 2003, p. 419, qtd. in Lange, 2014, p. 159) through these stories and a repository is created to deeply reinforce them in the viewers' minds. According to Keane, semiotic ideologies are "basic assumptions about what signs are and how they function in the world" (2003, p. 419). The patriarchal ideologies of servitude, sacrifice, and bondage to the husband's family are endorsed in these stories through familiar signs. For instance, the wife massaging the husband's feet serves as a sign of submissiveness, "bahus" mostly shown with their heads covered with their saree pallus (ends), whether she is an IAS officer or a homemaker, as signs of showing respect to men and elders, etc.

The concept of "symbolic annihilation of women in mass media" employed by Gaye Tuchman (1978) while studying the reflection hypothesis of how media reflects the society is quite relevant here. Analyzing how media perpetuates the prevailing sexual division of labor and orthodox gender roles of femininity and masculinity in the society, she foregrounds how media reinforces time and again the roles of a woman as daughter, wife, mother, etc., above all else. The moral stories discussed here follow such a pattern too. A woman is reduced to a "bahu" or daughter-in-law in most cases, even when the videos supposedly flaunt the success stories of women. The woman's role as a daughter is also limited in these digital representations, and where she is one, parents are reminded to raise daughters as prospective wives or daughters-in-law who will be good looking, hardworking and subservient or else they will become unattractive, lazy, arrogant and selfish. Patrilocal practice is promoted by many of these stories, when the adherence to the patrilocal structure has been identified as one of the reasons for the "dowry inflation in ... India" by Siwan Anderson (2003, p. 269). Incorporating the findings of Botticini and Siow (2002) on the functioning of a patrilocal society, Anderson says: "Dowry payments in this context will disappear when the development process is such that male children are less likely to work and live with their parents" (2003, p. 295).

Depending on culinary and homemaking skills when converted into a business idea certainly offers women the possibility to gain financial independence. But if majority of women bank solely on such skills to emerge as independent, and stay away from other professions, it will undo years of battle which helped women enter male dominated public spaces and institutions and be active agents of social processes. There are still households in India where boys are given 
support to pursue their education while girls are discouraged because of social, cultural and economic reasons. Stories which promote the idea of distance learning for girls instead of regular schooling ("Choti Bahu Bani Collector", "Dosa wali's Success", etc.) too are a cause for concern as they reinforce the existing belief that a girl or a woman should first take care of her family and think about education and employment only if circumstances demand or permit. In the COVID situation, studies prove that virtual learning has helped girls, where they get this opportunity, but in many cases, this opportunity has been denied to them due to multiple reasons (Chaudhary, 2021; Rana, 2021; etc.).

Digitalization of ideologies serves to further them, preserve them, and prevent them from getting uprooted, as digital texts, especially those found on YouTube can be easily accessed, viewed over and again, shared, made viral and can come back in another form. Richard Lanham's description of an electronic text is rightly applicable here: "You can have your cake, give it away, then eat it and still have it" (1993, p. xii). There has been a mushrooming of such moral stories on YouTube, of late, most of which are mindless recreation of another story, and yet a good many of them manage to get over a million views, which shows the underlying power they have in attracting the viewers' attention in a short span, despite the replication of content and presentation. To the video makers and to the average viewer, the successful "samosawali" or the "macchiwali" becomes the symbol of a successful woman not just because she succeeds in her chosen job but more so because she is an "ideal" wife or a daughter-in-law who knows the value of sacrifice and lives by the 'moral' fabric of patriarchy deeply entrenched in the society. As David Peetz observes, "The domestic sphere is a central factor in gender segmentation of the labour force - perhaps, ultimately, the driving force for the durability of gender inequality" (2019, p. 213). The moral stories on YouTube are certain that women should work and earn, if circumstances demand but there is still a reluctance to acknowledge a woman as an individual. A woman is expected to fulfill her filial duties first before she can think of an education or employment, as far as these stories go. And based on the viewership, comments and surge in stories with similar themes, it can be concluded that majority of viewers too applaud and accept this semiotic ideological power of visual digital narratives in inculcating certain values which they fear might be fast getting challenged if not disappearing from their immediate society and thus (re)instill them in their everyday existence. Under such circumstances, it becomes imperative to question and if required censor regressive content on easily accessible platforms like YouTube to limit their influence on children and young adults.

\section{Endnotes}

\footnotetext{
' These stories fall within the binary cis-gender system and hence the paper looks at the issues that come up within these representations.

ii Mother-in-law - daughter-in-law.

iii Success.

iv Indian Administrative Service
} 
9 | Digital Dose of Didactics: Reinforcing Patriarchy through Moral Stories on YouTube

v Das's comment is found with Dholakia's article (2015) - comment titled "A follow up thought from experience" and dated 10 January 2016.

vi From Probst's "Readers and Literary Texts." This is also employed by Jeffrey Kobrin in his thesis The Story of the Moral: On the Power of Literature to Define and Refine the Self (2018), but here it is not applied exactly as Kobrin does.

\section{References}

Anderson, S. (2003). Why dowry payments declined with modernization in Europe but are rising in India. The Journal of Political Economy, 111(2), 269-310. http://www.jstor.org/stable/3555204

Arjunwadkar, L. (1984). Woman in didactic fable and popular tale in Sanskrit. Annals of the Bhandarkar Oriental Research Institute, 65 (1), 155-162. https://www.jstor.org/stable/41693112

Burton, N. (2017, August 4). A feminist critique of marriage. Psychology Today. https://www.psychologytoday.com/us/blog/hide-and-seek/201708/feminist-critique-marriage

Chaudhary, M. (2021, July 31). COVID-19 rolls back progress on female education in India. East Asia Forum. https://www.eastasiaforum.org/2021/07/31/covid-19-rolls-back-progress-on-femaleeducation-in-india/

Dholakia U. (2015, December 15). How do Indian women fare in an arranged marriage?. Psychology Today. https://www.psychologytoday.com/us/blog/the-science-behind-behavior/201512/how-doindian-women-fare-in-arranged-marriage

Hindi Stories for Kids. (2019, October 28). Magical bakery wali [Video]. YouTube. https://youtu.be/-gIyMußazo

Irani, L. (2019). Chasing innovation: Making entrepreneurial citizens in modern India. Princeton University Press.

Jadu TV - Hindi Moral Stories. (2019, October 8). Dosawali ki safalta [Video]. YouTube. https://youtu.be/e16wCeWnJGk

Keane, W. (2003). Semiotics and the social analysis of material things. Language \& Communication, 23(34), 409-425. https://doi.org/10.1016/S0271-5309(03)00010-7

Kid Logics Bedtime Stories. [2019, September 29]. Naukriwali bahu [Video]. YouTube. https://youtu.be/WN3jKr4zksY

Kid Logics Bedtime Stories. (2019, October 24). Sheher ki saas [Video]. YouTube. https://youtu.be/uWmWmDlyO8o

KirraK TV. (2020, February 16). Bulldozer marriage kahani comedy [Video]. YouTube. https://youtu.be/nHMIrziKj4

Kobrin, J. B. (2018). The story of the moral: On the power of literature to define and refine the self. $[\mathrm{PhD}$ thesis: Columbia University]. academiccommons.columbia.edu , doi , download PDF

Koo Koo TV-Hindi. (2019, June 22). Machiwali ki safalta [Video]. YouTube. https://youtu.be/YKJcA_JKck0

Koo Koo TV-Hindi. (2019, July 25). Gol matol bahu [Video]. YouTube. https://youtu.be/SxpYeQ91d8o

Koo Koo TV-Hindi. [2019, November 7]. "Moochowali ladki" [Video]. YouTube. https://youtu.be/eUj_u7JMQW8 
10 | Rupkatha Journal, Vol. 13, No. 4, 2021

Koo Koo TV-Hindi. (2019, December 2). Road Roller wali bahu [Video]. YouTube. https://youtu.be/tZcfrTLXmzo

Lange, P. G. (2014). "Representational ideologies." In Kids on YouTube: Technical identities and digital literacies (pp. 157-188). Left Coast Press.

Lanham, R. A. (1993). The electronic word: Democracy, technology and the arts. University of Chicago Press.

MaJa Tv Hindi Stories. (2019, July 3). Samosawali ki safalta [Video]. YouTube. https://youtu.be/fyYMGfu5pOM

MaJa Tv Hindi Stories. (2019, July 17). Choti bahu bani collector [Video]. YouTube. https://youtu.be/nisz4t3ZIRw

Nelms, B. F. (Ed.). (1988). Literature in the classroom: Readers, texts and contexts. NCTE.

Ojha, P. (2011). Women's issues in India: Role and importance of media. The Indian Journal of Political Science, 72(1), 87-102. JSTOR. https://www.jstor.org/stable/42761809

Peetz, D. (2019). Women and segmentation. In The Realities and futures of work (pp. 210-246). JSTOR. https://www.jstor.org/stable/j.ctvq4c16w.13

Rana, D. (2021, September 7). COVID-19, India, and girls' education. Harvard Political Review. https://harvardpolitics.com/covid-19-girls/

Red Tomato. (2020, January 31). Mooch wali ladki [Video]. YouTube. https://youtu.be/SoNQaV9BHVo

Smagorinsky, P., \& Taxel J. (2010). The discourse of character education: Culture wars in the classroom. Routledge.

Tuchman, G. (1978). Introduction: The symbolic annihilation of women by the mass media. In Gaye Tuchman, Arlene Kaplan Daniels, and James Benet (Eds.), Hearth and home: Images of women in the mass media (pp. 3-38). Oxford University Press. 